\title{
Effect of flaxseed supplementation rate and processing on the production, fatty acid profile, and texture of milk, butter, and cheese
}

\author{
S. P. Oeffner, ${ }^{*}$ Y. Qu, ${ }^{*}$ J. Just, $\dagger$ N. Quezada, ${ }^{*}$ E. Ramsing, ${ }^{*}$ M. Keller, ${ }^{*}$ G. Cherian, ${ }^{*}$ L. Goddick, $\dagger$ \\ and $\mathbf{G}$. Bobe ${ }^{*} \ddagger^{1}$ \\ *Department of Animal and Rangeland Sciences, \\ †Department of Food Science and Technology, and \\ łLinus Pauling Institute, Oregon State University, Corvallis 97331
}

\section{ABSTRACT}

Health and nutrition professionals advise consumers to limit consumption of saturated fatty acids and increase the consumption of foods rich in n-3 fatty acids. Researchers have previously reported that feeding extruded flaxseed, which is high in C18:3n-3, improves the fatty acid profile of milk and dairy products to less saturated fatty acids and to more C18:3n-3. Fat concentrations in milk and butter decreased when cows were fed higher concentrations of extruded flaxseed. The objective of this study was to determine the optimal rate of flaxseed supplementation for improving the fatty acid profile without decreasing production characteristics of milk and dairy products. By using a double $5 \times 5$ Latin square design, $10 \mathrm{mid}-$ to late-lactation Holstein cows were fed extruded $(0,0.91,1.81$, and $2.72 \mathrm{~kg} / \mathrm{d})$ and ground $(1.81 \mathrm{~kg} / \mathrm{d})$ flaxseed as a top dressing for 2 -wk periods each. At the end of each 2-wk treatment period, milk and serum samples were taken. Milk was subsequently manufactured into butter and fresh Mozzarella cheese. Increasing supplementation rates of extruded flaxseed improved the fatty acid profile of milk, butter, and cheese gradually to less saturated and atherogenic fatty acids and to more C18:3n-3 by increasing concentrations of C18:3n-3 in serum. The less saturated fatty acid profile was associated with decreased hardness and adhesiveness of refrigerated butter, which likely cause improved spreadability. Supplementation rates of extruded flaxseed did not affect dry matter intake of the total mixed ration, milk composition, and production of milk, butter, or cheese. Flaxseed processing did not affect production, fatty acid profile of milk, or texture of butter and cheese. Feeding up to $2.72 \mathrm{~kg} / \mathrm{d}$ of extruded flaxseed to mid- to late-lactation Holstein cows may improve nutritional and functional properties of milk fat without compromising production parameters.

Received July 14, 2012.

Accepted October 21, 2012.

${ }^{1}$ Corresponding author: gerd.bobe@oregonstate.edu
Key words: dairy product, fatty acid composition, flaxseed, texture

\section{INTRODUCTION}

Milk and dairy products contribute significantly to the consumption of essential nutrients in human populations (Drewnowski, 2011). Despite its important roles in human nutrition, consumption of milk has declined over the last decades (Haug et al., 2007), as nutritional guidelines have advised limiting the per capita consumption of SFA, which to a significant proportion originate from milk and dairy products (USDA and HHS, 2010). Many nutritional and medical associations promote the consumption of diets rich in $\mathrm{n}-3 \mathrm{FA}$, including $\mathrm{C} 18: 3 \mathrm{n}-3$, which are found in low concentrations in milk fat (IOM, 2002; Kris-Etherton et al., 2007). To improve the FA profile of milk and dairy products, the cow's diet can be supplemented with oilseeds, which decrease the proportion of SFA, including atherogenic C12:0, C14:0, and C16:0, by decreasing de novo FA synthesis in the mammary gland (reviewed by Glasser et al., 2008a).

Flaxseed is one of the most widely researched oilseeds for dairy nutrition (reviewed by Petit, 2010) and contains $55 \%$ of its FA as C18:3n-3 (Bean and Leeson, 2002). Feeding flaxseed provides a dual benefit, as it improves the nutritional profile of milk fat by decreasing the proportion of atherogenic FA and by increasing the proportion of C18:3n-3 (Glasser et al., 2008a). Functional properties of refrigerated butter are also improved, as indicated by increased spreadability and melting in the mouth (Hurtaud et al., 2010). Although the processing technique of flaxseed, in general, does not affect milk composition (Petit, 2010), cows fed extruded flaxseed (EF) had lower milk fat concentrations than did cows fed raw flaxseed (Gonthier et al., 2005; Martin et al., 2008), and EF decreased linearly milk and butter fat content (Hurtaud et al., 2010), thereby decreasing economic returns of producers and processors. 
To determine the optimal rate of flaxseed supplementation for improving the nutritional and functional properties of milk products without decreasing production parameters, at least 4 supplementation rates of flaxseed within an experiment are necessary. So far, however, the maximal number of tested rates of flaxseed within an experiment has been 3 and limited to 2 articles: 0,1 , or $1.4 \mathrm{~kg}$ of ground flaxseed/d by Collomb et al. (2004) and $\mathrm{EF}$ at $0,2.1$, or $4.3 \%$ of ration by Hurtaud et al. (2010). Therefore, the objective of this study was to evaluate the effect of 4 supplementation rates of $\operatorname{EF}(0,0.91,1.81$, and $2.72 \mathrm{~kg} / \mathrm{d})$ and processing technique (ground vs. EF) on the production, composition, FA profile, and texture of milk, butter, and cheese from lactating dairy cows. We hypothesized that an optimal supplementation rate exists for feeding $\mathrm{EF}$ at which the nutritional and functional properties of milk products are maximized and production characteristics are maintained. Improved nutritional properties are indicated by milk fat lower in atherogenic FA and higher in C18:3n-3. Improved functional properties are indicated by softer butter texture at refrigeration temperature. Maintained production characteristics are indicated by preventing decreased DMI, decreased milk fat content, and increased BW.

\section{MATERIALS AND METHODS}

\section{Animals and Diets}

Ten confirmed pregnant, lactating Holstein dairy cows (DIM at beginning of study: 168 to $285 ; 5$ cows in first lactation, 3 cows in second lactation, and 2 cows in third lactation) that were housed at the Oregon State University Dairy Center (Corvallis) were used for the feeding study. Cows were selected for the study to be at a similar stage of lactation, pregnancy, and level of milk production. Cows were fed individually via Calan gates (American Calan Inc., Northwood, NH) twice daily (0700 and $1900 \mathrm{~h}$ ) a TMR that was formulated to meet NRC (2001) requirements for lactating Holstein cows (Table 1). All procedures involving animals were conducted in accordance with Oregon State University Institutional Animal Care and Use guidelines (ACUP No. 4013). The experiment was performed in accordance with guidelines established in the Federation of Animal Science Societies Guide for the Care and Use of Agricultural Animals in Research and Teaching (FASS, 2010).

The study design was a double $5 \times 5$ Latin square. Cows were blocked by parity (primiparous or multiparous) and randomly assigned to 5 treatment groups. During morning feeding, cows received as top dressing to their TMR 1 of each of the 5 supplements $(0,0.91$,
1.81 , or $2.72 \mathrm{~kg}$ of $\mathrm{EF} / \mathrm{d}$; OmegaBoost; Double Pass LLC, Tualatin, OR), or $1.81 \mathrm{~kg}$ of ground flaxseed/d (from the same batch that was used to manufacture $\mathrm{EF}$ ) for $14 \mathrm{~d}$ without washout period in between (Table 2 ). The whole study lasted $10 \mathrm{wk}$. OmegaBoost is manufactured by using a patent-pending process characterized by the grinding, chemical and heat treatment, extrusion, and processing of flaxseed into cylindrical pellets $(3-\mathrm{cm}$ long $\times 0.4-\mathrm{cm}$ thick) that have a darker brown color than ground flaxseed powder. Feed intake was daily adjusted to have at least $10 \%$ feed refusal. One cow injured her leg in the fourth feeding period and was dropped from the study. The results of the first 3 feeding periods of the injured cow were included in the statistical analysis.

The supplementation rates of $\mathrm{EF}$ were selected to cover the supplementation rates for raw and processed flaxseed previously published in the literature (Hurtaud et al., 2010; as reviewed by Petit, 2010). The supplementation rates had been tested in preliminary experiments and did not show adverse effects on DMI or milk production (results not shown). The supplementation rate of ground flaxseed was chosen to be the same as an intermediate supplementation rate of EF.

\section{Sample Collection}

Activity and resting times between milkings, BW, and milk production and composition from each cow

Table 1. Composition of TMR

\begin{tabular}{lc}
\hline Item & TMR \\
\hline Ingredient (\% of DM) & \\
Alfalfa & 29.9 \\
Grass silage & 29.6 \\
Concentrate & 40.5 \\
Barley & 29.5 \\
Corn & 29.46 \\
Wheat & 17 \\
Dried distillers grain & 11.75 \\
Canola meal & 4.1 \\
Soybean meal, high protein & 3.1 \\
Calcium carbonate & 1.75 \\
Sodium chloride & 1.205 \\
Bicarbonate & 0.795 \\
Magnesium oxide, $58 \%$ & 0.475 \\
Urea & 0.4 \\
LDH Fortifier ${ }^{1}$ & 0.3 \\
RU-Max Plus ${ }^{1}$ & 0.139 \\
Sel-Plex 2700 & 0.024 \\
Chemical composition (g/kg, unless otherwise noted) & \\
DM (\%) & 55.1 \\
NE (Mcal/kg of DM) & 1.68 \\
CP (\% of CP) & 185 \\
RUP (\% & 30.9 \\
NDF & 174 \\
ADF & 96 \\
NFC & 395 \\
Fat & 34.8 \\
\hline Agr-King Inc. Futon &
\end{tabular}

${ }^{1}$ Agri-King Inc., Fulton, IL. 
Table 2. Lipid and FA profile of flaxseed supplements $(\mathrm{n}=2)$

\begin{tabular}{lcc}
\hline Lipid/FA & $\begin{array}{c}\text { Ground } \\
\text { flaxseed }\end{array}$ & $\begin{array}{c}\text { Extruded } \\
\text { flaxseed }\end{array}$ \\
\hline Concentration (g/kg of DM) & & \\
Total lipid & 365 & 306 \\
cis-9 C18:1 & 58 & 56 \\
C18:2 & 48 & 47 \\
C18:3 & 215 & 172 \\
FA composition (wt \%) & 6.6 & \\
C16:0 & 0.5 & 5.8 \\
C16:1 & 4.8 & 0.2 \\
C18:0 & 15.8 & 4.1 \\
cis-9 C18:1 & 13.2 & 18.2 \\
C18:2n-6 & 59.1 & 56.4 \\
C18:3n-3 & & \\
\hline
\end{tabular}

were measured after each milking (0600 and $1800 \mathrm{~h})$ by using the Affimetrix system (Kibbutz Afikim, Israel) and averaged for each cow and 14-d feeding period for statistical analysis. To determine the milk FA composition, a composite milk sample was taken from each cow on the last day of each 14-d feeding period and stored at $-20^{\circ} \mathrm{C}$ until analysis. To determine serum metabolite and FA concentrations, a blood sample from each cow was collected from the coccygeal vein or artery on the last morning $(0600 \mathrm{~h})$ of each 14-d feeding period. Blood samples were collected in serum Vacutainer tubes (BD Vacutainer Plus plastic serum tubes; BD Diagnostics, Franklin Lakes, NJ) and placed on ice immediately after collection. Within 30 min of collection, serum was transferred after centrifugation at 1,600 $\times g$ for $20 \mathrm{~min}$ and stored at $-20^{\circ} \mathrm{C}$ until analysis.

\section{Butter and Mozzarella Cheese Manufacture}

Milk was collected from each cow in stainless steel milk cans on the last morning (0600 h) of each 14-d feeding period for manufacture into butter and cheese. Within $4 \mathrm{~h}$ of collection, milk from each cow $(8 \mathrm{~L} / \mathrm{cow})$ was pasteurized in double-boiler pots at $63^{\circ} \mathrm{C}$ for $30 \mathrm{~min}$ and then cooled to $15^{\circ} \mathrm{C}$. The pasteurized milk from the 2 cows receiving the same treatment were combined and then used at equal amounts (8 L) for butter and Mozzarella cheese manufacture.

For butter manufacture, cream was separated by using a DeLaval model 100 (The DeLaval Separator Co., Poughkeepsie, NY) electric cream separator and stored overnight at $4^{\circ} \mathrm{C}$. The following day, an electric mixer (model KHM7GTN2; KitchenAid, St. Joseph, MI) operated at the speed setting of 3 or 4 at $5^{\circ} \mathrm{C}$ was used to churn the cream into butter. One cream sample did not churn into butter $(1.81 \mathrm{~kg}$ of processed flaxseed/d, third feeding period). The next morning, butter was vacuum packed using a FoodSaver V2450 bag sealer (Jarden
Consumer Solutions, Boca Raton, FL), weighed, and stored at $-80^{\circ} \mathrm{C}$ until further analysis.

For cheese manufacture, $8 \mathrm{~L}$ of milk was acidified with $237 \mathrm{~mL}$ of distilled white vinegar (5\% acidity). The acidified milk ( $\mathrm{pH} 5.5)$ at $15^{\circ} \mathrm{C}$ was then gently stirred while the temperature was raised to $33^{\circ} \mathrm{C}$ in a double boiler pot. While stirring, $1.23 \mathrm{~mL}$ of singlestrength liquid rennet (DCI Veal; Dairy Connection Inc., Madison, WI) was diluted 1:10 (vol/vol) with distilled water and slowly poured into the milk. Stirring was continued for $1 \mathrm{~min}$ to ensure uniform incorporation into the milk. Stirring was discontinued to allow curd formation. Once the curd formed a clean break, which took approximately $5 \mathrm{~min}$, it was cut into $1.25 \times 1.25 \times 1.25-\mathrm{cm}$ cubes, and then rested. The temperature was raised over a $30-\min$ period to $40.5^{\circ} \mathrm{C}$ while the curd was gently lifted from the bottom of the boiler to prevent matting. After $30 \mathrm{~min}$, the whey was drained through a food safe plastic colander until the curd completely matted.

The matted curd was then cut into 4 approximately equal pieces, which were then immersed separately in $77^{\circ} \mathrm{C}$ water until the curd became soft and malleable. Once malleable, the curd was worked together until the structure was semi-firm and the surface became glossy. The 4 cheese loaves were cooled for $30 \mathrm{~min}$ in ice water baths, 2 of which were saturated with brine solution. The 4 cheese loaves were stored overnight at $4^{\circ} \mathrm{C}$ and the next morning vacuum packed using a FoodSaver V2450 bag sealer. Cheese loaves were weighed and stored at $-80^{\circ} \mathrm{C}$ until further analysis.

\section{Lipid and FA Analysis}

Lipids of the extruded and ground flaxseed were extracted and quantified in duplicate by using an ether extract method (AOAC, 1990; method 962.09). Before lipid extraction, the EF pellets were ground in a Proctor-Silex coffee grinder (model E160B; Hamilton Beach/Proctor Silex Inc., Southern Pines, NC). The ether extracts of the ground flaxseed and EF were stored at $-20^{\circ} \mathrm{C}$. The fat content of cheese was determined with a rapid solvent extraction method (AOCS, 2004; approved procedure Am 5-04) using an Ankom ${ }^{\mathrm{XT} 10}$ fat analyzer (Ankom Technology Corp., Macedon, NY).

For FA analysis, lipids were extracted from ground flaxseed, EF, serum, milk, butter, and cheese as described by Folch et al. (1957). In short, $9 \mathrm{~mL}$ of chloroform:methanol $(2: 1 ; \mathrm{vol} / \mathrm{vol})$ was added to $3 \mathrm{~mL}$ of serum or milk or $2 \mathrm{~g}$ of flaxseed, butter, or cheese, combined by using an analog vortex mixer for $30 \mathrm{~s}$, and left overnight at $4^{\circ} \mathrm{C}$. Four milliliters of $0.88 \% \mathrm{NaCl}$ solution was added to the sample tubes and inverted to 
mix. Sample tubes were then centrifuged for $10 \mathrm{~min}$ at $1,800 \times g$. After centrifugation, the aqueous top layer was removed by suction and lipid extract was obtained by filtration through Whatman 1 filter paper (Whatman International Ltd., Maidstone, UK).

Internal standard solution (1\% C13:0 wt/wt in butanol; Nu-Chek Prep Inc., Elysian, MN) was added at a volume of $25 \mu \mathrm{L}$ (for serum, milk, or ether extract of flaxseed), $50 \mu \mathrm{L}$ (for butter), or $150 \mu \mathrm{L}$ (for cheese) to $1.5 \mathrm{~mL}$ of lipid. The mixture was dried under nitrogen and methylated by using $2 \mathrm{~mL}$ of boron-trifluoride solution. Test tubes were incubated at 90 to $100^{\circ} \mathrm{C}$ for $1 \mathrm{~h}$. Fatty acid methyl esters were recovered by washing the sample with $2 \mathrm{~mL}$ of hexane and then $2 \mathrm{~mL}$ of water, and then removing the top hexane layer for FA analysis using a pipette.

Fatty acid methyl esters were separated and quantified using an automated gas chromatograph (Agilent 6890; Agilent Technologies Inc., Palo Alto, CA) equipped with an autosampler and flame ionization detector and a $100-\mathrm{m} \times 0.25-\mathrm{mm} \times 0.20-\mu \mathrm{m}$-film-thickness Supelco 2560 fused silica capillary column (Supelco Inc., Bellefonte, PA). The initial column temperature was set at $60^{\circ} \mathrm{C}$ for $4 \mathrm{~min}$, increased to $165^{\circ} \mathrm{C}$ at $4^{\circ} \mathrm{C} / \mathrm{min}$, and maintained for $2 \mathrm{~min}$. Next, the column temperature was elevated to $200^{\circ} \mathrm{C}$ at a rate of $15^{\circ} \mathrm{C} / \mathrm{min}$ and maintained at the final temperature for $30 \mathrm{~min}$. Helium was used as the carrier gas at a flow rate of $1.0 \mathrm{~mL} / \mathrm{min}$. The flame ionization detector was set at $250^{\circ} \mathrm{C}$.

\section{Texture Analysis of Butter and Cheese}

Butter and cheese texture analysis was done using a Stable Micro Systems TA-XT2 texture analyzer (Texture Technologies Corp., Scarsdale, NY), after all samples had been manufactured. Butter and cheese samples were cut in 2.5 -cm wide $\times 10$-cm long $\times 2$-cm deep rectangular boxes, and the texture was analyzed at refrigeration temperature $\left(4^{\circ} \mathrm{C}\right)$ and room temperature $\left(23^{\circ} \mathrm{C}\right)$. For textural analysis, a 6 - $\mathrm{mm}$ cylindrical probe (P6) was advanced at $1 \mathrm{~mm} / \mathrm{sec}$ until it reached a depth of $12 \mathrm{~mm}$ for butter and $10 \mathrm{~mm}$ for cheese. The penetration force (in $g$ ) was recorded after the probe contacted that sample and reached the minimal trigger force ( $5 \mathrm{~g}$ for cheese and $3 \mathrm{~g}$ for butter). The hardness was measured as the maximal force required for initial penetration, and the force required to retract the probe after penetration was reported as the measure of adhesiveness. Measures of hardness and adhesiveness were taken in triplicate at $23^{\circ} \mathrm{C}$, and the average was used for statistical analysis. At $4^{\circ} \mathrm{C}$, the hardness and adhesiveness decreased proportionally to the amount of time that the samples spent out of the refrigera- tor. Therefore, we used only the first measurement for statistical analysis.

\section{Serum Metabolite Analysis}

Concentrations of glucose (Stanbio glucose procedure no. 1075; Stanbio Laboratory; Boerne, TX), NEFA (ACS ACOD method; Wako Diagnostics, Richmond, VA), BHBA (Stanbio BHBA LiquiColor procedure no. 2440; Stanbio Laboratory), and urea nitrogen (Stanbio Urea Nitrogen Liqui-UV Test; Stanbio Laboratory) in serum were quantified according to manufacturer's instructions that were adapted for microplate reader use with a FLUOstar Omega microplate autoreader (BMG Labtech Inc., San Francisco, CA).

\section{Statistical Analysis}

Data were analyzed as a double $5 \times 5$ Latin square design using PROC MIXED of SAS (SAS Institute, 2001). The fixed effects were supplement $(0,0.91,1.81$, or $2.72 \mathrm{~kg}$ of EF/d and $1.81 \mathrm{~kg}$ of ground flax seed/d), feeding period $(1,2,3,4$, or 5$)$, and, except for butter and cheese measurements, parity (primiparous or multiparous), and the interaction between supplement and feeding period. A first-order autoregressive variance-covariance matrix was used to adjust for variation within cow over time. Preplanned contrasts were performed. To determine the dose response of EF, linear, quadratic, and cubic contrasts were constructed using the ESTIMATE statement. The effect of flaxseed processing was evaluated by comparing the results for 1.81 $\mathrm{kg} / \mathrm{d}$ extruded versus ground flaxseed. The standard errors of the mean shown in the tables are the largest standard errors of the 5 treatment groups. Statistical significance was declared at $P \leq 0.05$ and a tendency at $0.05<P \leq 0.10$.

\section{RESULTS}

\section{Cow Performance}

Supplementation with EF increased total DMI in a linear manner $\left(P_{\text {Linear }}=0.03\right)$, whereas DMI of the TMR remained similar (Table 3 ). Cows consumed the flaxseed supplement within 5 min, except for ground flaxseed and the highest dosage of EF, which were consumed within 30 min. Daily supplementation with 0.91 , 1.81 , and $2.72 \mathrm{~kg}$ of EF increased the lipid intake by $0.26,0.52$, and $0.78 \mathrm{~kg}$, respectively, and $\mathrm{C} 18: 3 \mathrm{n}-3$ consumption by $0.14,0.28$, and $0.42 \mathrm{~kg}$, respectively. Extruded flaxseed contained $16 \%$ less lipid per kilogram of DM than ground flaxseed (30.6 vs. $36.5 \%$; Table 2). As 
a result, $1.81 \mathrm{~kg}$ of ground flaxseed increased lipid and C18:3n-3 intake by 0.62 and $0.37 \mathrm{~kg} / \mathrm{d}$, respectively, compared with 0.52 and $0.29 \mathrm{~kg} / \mathrm{d}$, respectively, by EF. The lipid intake for cows that received $0,0.91,1.81$, and $2.72 \mathrm{~kg}$ of EF and $1.81 \mathrm{~kg}$ of ground flaxseed/d was $3.52,4.60,5.64,6.54$, and $6.03 \%$ of DM, respectively. Despite the greater DMI and the higher dietary energy concentrations when cows received flaxseed, no significant increases in BW or milk production and composition were observed (Table 3). Similarly, no differences in activity and resting time (Table 3 ) or changes in concentrations of glucose, BHBA, urea $\mathrm{N}$, and NEFA in serum were detected (Table 3 ).

\section{Serum FA Concentration}

As expected, supplementation of EF tended to increase linearly concentrations of total FA in serum ( $18 \%$ increase from 0 to $2.72 \mathrm{~kg}$ of EF $\left./ \mathrm{d} ; P_{\text {Linear }}=0.09\right)$ by increasing the concentrations of MUFA $(+34 \%$; $\left.P_{\text {Linear }}=0.08\right)$ and PUFA $\left(+15 \% ; P_{\text {Linear }}=0.09\right.$; Table 4). Changes in individual FA concentrations in serum reflected the FA composition of flaxseed. The primary FA in flaxseed, C18:3n-3 (Table 2), was increased lin- early by $96 \%$ from 0 to $2.72 \mathrm{~kg}$ of $\mathrm{EF} / \mathrm{d}\left(P_{\text {Linear }}<0.001\right.$; Figure 1), whereas the second most common FA in flaxseed, cis $\mathrm{C} 18: 1$, was increased by $27 \%\left(P_{\text {Linear }}=0.05\right.$; Table 4). Processing of flaxseed did not significantly affect FA concentrations in serum (Table 4).

\section{Milk FA Composition}

Supplementing EF, which is rich in unsaturated FA, altered the milk FA composition to a more unsaturated profile. By feeding 2.72 rather than $0 \mathrm{~kg}$ of $\mathrm{EF} / \mathrm{d}$, the proportion of SFA decreased $\left(-18 \% ; P_{\text {Linear }}<0.001\right)$ and the proportion of MUFA $\left(+35 \%\right.$; $\left.P_{\text {Linear }}<0.001\right)$ and PUFA increased $\left(+82 \% ; P_{\text {Linear }}=0.001\right.$; Table 5$)$. Feeding EF increased de novo synthesized milk FA C6:0 to $\mathrm{C} 16: 0\left(-23 \%\right.$; $\left.P_{\text {Linear }}<0.001\right)$, including the proportion of the atherogenic FA C12:0, C14:0, and C16:0 $\left(-23 \% ; P_{\text {Linear }}<0.001 ;\right.$ Figure $\left.2 \mathrm{~A}\right)$. Conversely, total C18:1 $\left(+39 \% ; P_{\text {Linear }}<0.001\right)$, especially trans $\mathrm{C} 18: 1$ $\left(+124 \% ; P_{\text {Linear }}=0.001\right)$, and equally, C18:2 $(+87 \%$; $\left.P_{\text {Linear }}=0.003\right)$ and C18:3n-3 $\left(+70 \% ; P_{\text {Linear }}<0.001\right.$; Figure 2B), increased in milk fat by feeding EF (Table 5). Processing of flaxseed did not significantly affect milk FA composition (Table 5).

Table 3. Effect of flaxseed supplementation rate and processing on cow performance and production

\begin{tabular}{|c|c|c|c|c|c|c|c|c|c|c|}
\hline Variable & \multicolumn{4}{|c|}{ Extruded flaxseed ${ }^{1}(\mathrm{~kg} / \mathrm{d})$} & $\begin{array}{l}\text { Ground } \\
\text { flaxseed }^{2}\end{array}$ & $\mathrm{SEM}^{3}$ & \multicolumn{4}{|c|}{ Contrast $^{4}(P$-value $)$} \\
\hline \multicolumn{11}{|l|}{ Cow performance } \\
\hline TMR DMI (kg) & 20.5 & 20.5 & 20.1 & 20.5 & 20.6 & 1.0 & 0.86 & 0.78 & 0.52 & 0.60 \\
\hline BW $(\mathrm{kg})$ & 749 & 757 & 755 & 755 & 753 & 15 & 0.62 & 0.43 & 0.43 & 0.75 \\
\hline Activity (min) & 130 & 121 & 124 & 122 & 123 & 11 & 0.64 & 0.64 & 0.52 & 0.97 \\
\hline Milk & 30.0 & 30.4 & 30.3 & 30.2 & 30.0 & 1.8 & 0.95 & 0.79 & 0.82 & 0.82 \\
\hline Fat & 1.25 & 1.30 & 1.29 & 1.28 & 1.28 & 0.06 & 0.80 & 0.54 & 0.61 & 0.88 \\
\hline Protein & 0.93 & 0.93 & 0.93 & 0.93 & 0.91 & 0.05 & 0.99 & 0.90 & 0.92 & 0.76 \\
\hline Lactose & 1.45 & 1.47 & 1.47 & 1.47 & 1.45 & 0.09 & 0.91 & 0.84 & 0.81 & 0.84 \\
\hline TS & 3.63 & 3.71 & 3.68 & 3.68 & 3.65 & 0.20 & 0.87 & 0.75 & 0.74 & 0.83 \\
\hline \multicolumn{11}{|c|}{ Milk composition (\%) } \\
\hline Fat & 4.20 & 4.31 & 4.28 & 4.27 & 4.30 & 0.16 & 0.73 & 0.41 & 0.56 & 0.87 \\
\hline BHBA $(\mathrm{m} M)$ & 0.65 & 0.70 & 0.59 & 0.50 & 0.54 & 0.08 & 0.15 & 0.36 & 0.48 & 0.63 \\
\hline Urea N (mg/dL) & 15.1 & 15.7 & 16.1 & 16.9 & 15.4 & 1.2 & 0.28 & 0.97 & 0.88 & 0.58 \\
\hline NEFA (mEq/L) & 127 & 104 & 91 & 135 & 99 & 27 & 0.93 & 0.22 & 0.66 & 0.82 \\
\hline
\end{tabular}

${ }^{1}$ Extruded flaxseed: $0=$ no additional lipid supplementation above that supplied by TMR; $0.91=0.28 \mathrm{~kg} / \mathrm{d}$ of supplemented fat from extruded flaxseed with $56 \%$ C18:3n-3; $1.81=0.56 \mathrm{~kg} / \mathrm{d}$ of supplemented fat from extruded flaxseed with $56 \%$ C18:3n-3; $2.72=0.83 \mathrm{~kg} / \mathrm{d}$ of supplemented fat from extruded flaxseed with $56 \%$ C18:3n-3.

${ }^{2}$ Ground flaxseed: $1.81 \mathrm{~kg} / \mathrm{d}$ of ground flaxseed $=0.66 \mathrm{~kg} / \mathrm{d}$ of supplemented fat from ground flaxseed with $59 \%$ C18:3n-3.

${ }^{3}$ The largest $\mathrm{SE}$ of the 5 treatment groups is shown.

${ }^{4} \mathrm{~L}=$ linear contrast between $0,0.91,1.81$, and $2.72 \mathrm{~kg}$ of extruded flaxseed $/ \mathrm{d} ; \mathrm{Q}=$ quadratic contrast between $0,0.91,1.81$, and $2.72 \mathrm{~kg}$ of extruded flaxseed $/ \mathrm{d} ; \mathrm{C}=$ cubic contrast between $0,0.91,1.81$, and $2.72 \mathrm{~kg}$ of extruded flaxseed $/ \mathrm{d} ; \mathrm{P}=$ effect of flaxseed processing; $1.81 \mathrm{~kg} / \mathrm{d}$ of extruded versus ground flaxseed. 


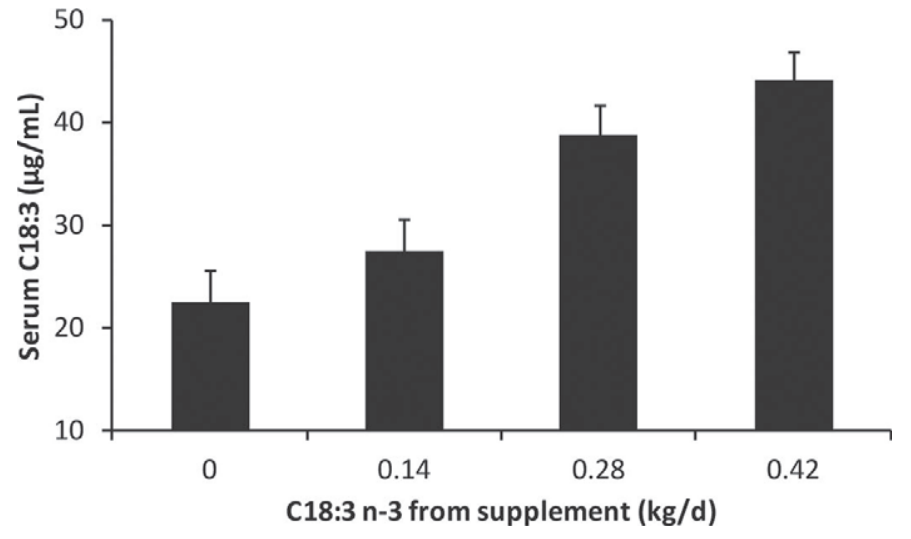

Figure 1. Effect of dietary C18:3n-3 supplementation rate by using extruded flaxseed on concentrations of C18:3n-3 in serum.

\section{Butter and Cheese FA Composition}

Changes in butter FA composition reflected changes in milk FA composition in response to flaxseed feeding (Table 6$)$. The proportion of SFA $\left(-17 \% ; P_{\text {Linear }}\right.$
$<0.001)$, including atherogenic FA $\left(-24 \% ; P_{\text {Linear }}<\right.$ 0.001; Figure 2A), decreased in response to feeding 2.72 rather than $0 \mathrm{~kg}$ of $\mathrm{EF} / \mathrm{d}$. Conversely, the proportion of MUFA $\left(+28 \%\right.$; $\left.P_{\text {Linear }}<0.001\right)$ and PUFA $(+73 \%$; $\left.P_{\text {Linear }}<0.001\right)$, including total C18:2 $\left(+79 \% ; P_{\text {Linear }}\right.$ $=0.002)$ and $\mathrm{C} 18: 3 \mathrm{n}-3\left(+66 \% ; P_{\text {Linear }}<0.001\right.$; Figure 2B), increased (Table 6). Processing of flaxseed did not significantly affect butter FA composition (Table 6). Compared with milk fat, butter fat had a lower proportion of FA up to C14:0, the decrease being greatest for C4:0 with approximately $-30 \%$ (Tables 5 and 6).

Changes in milk, butter, and cheese FA profile were similar in direction in response to feeding increasing amounts of flaxseed (Tables 5, 6, and 7). In fresh Mozzarella cheese, the proportion of SFA $\left(-18 \% ; P_{\text {Linear }}=\right.$ $0.01)$, including atherogenic FA $\left(-24 \% ; P_{\text {Linear }}=0.002\right.$; Figure 2A), decreased in response to feeding 2.72 rather than $0 \mathrm{~kg}$ of EF/d. Conversely, the proportion of MUFA $\left(+35 \% ; P_{\text {Linear }}=0.01\right)$ and PUFA $\left(+43 \% ; P_{\text {Linear }}=\right.$ $0.02)$, including C18:3n-3 $\left(+42 \%\right.$; $P_{\text {Linear }}=0.001$; Figure $2 \mathrm{~B}$ ), increased (Table 7). Processing of flaxseed did

Table 4. Effect of flaxseed supplementation rate and processing on serum FA concentrations

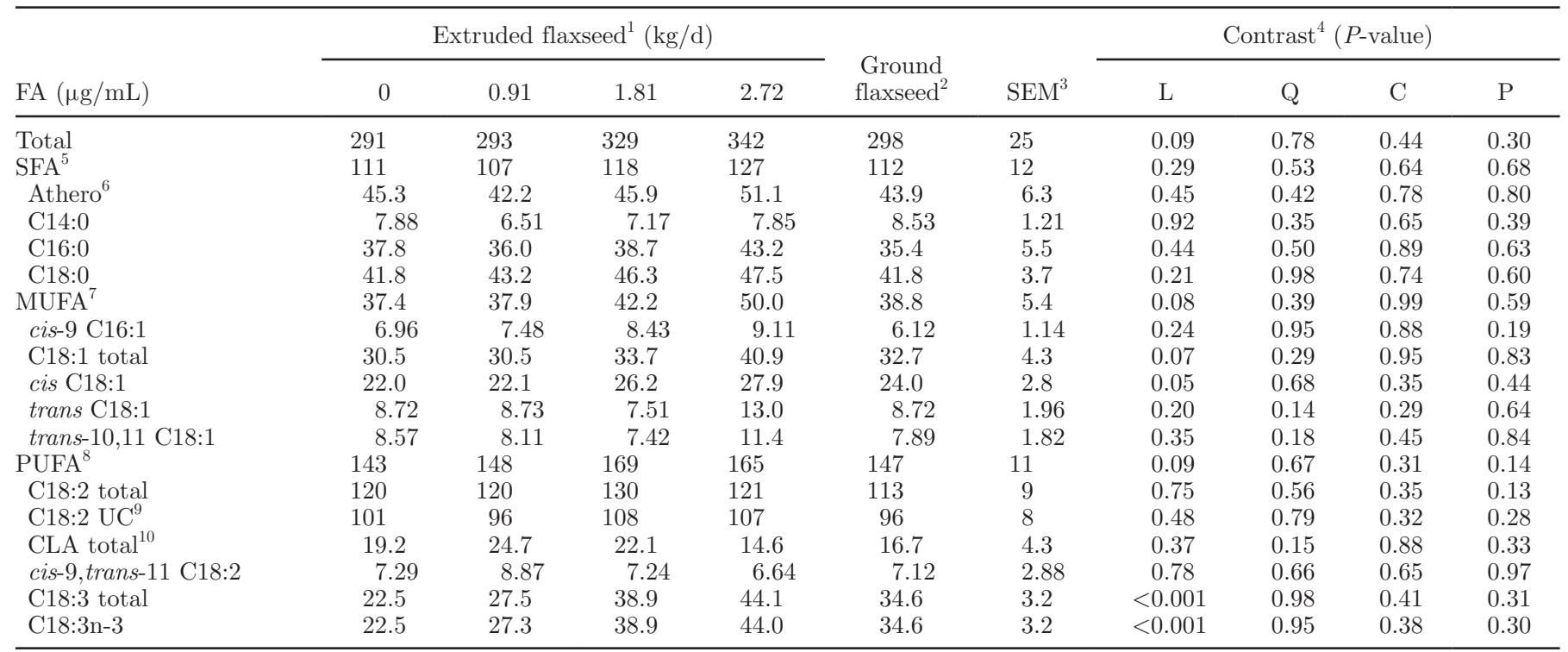

${ }^{1}$ Extruded flaxseed: $0=$ no additional lipid supplementation above that supplied by TMR; $0.91=0.28 \mathrm{~kg} / \mathrm{d}$ of supplemented fat from extruded flaxseed with $56 \%$ C18:3n-3; $1.81=0.56 \mathrm{~kg} / \mathrm{d}$ of supplemented fat from extruded flaxseed with $56 \% \mathrm{C} 18: 3 \mathrm{n}-3 ; 2.72=0.83 \mathrm{~kg} / \mathrm{d}$ of supplemented fat from extruded flaxseed with $56 \%$ C18:3n-3.

${ }^{2}$ Ground flaxseed: $1.81 \mathrm{~kg} / \mathrm{d}$ of ground flaxseed $=0.66 \mathrm{~kg} / \mathrm{d}$ of supplemented fat from ground flaxseed with $59 \%$ C18:3n-3.

${ }^{3}$ The largest standard error of the 5 treatment groups is shown.

${ }^{4} \mathrm{~L}=$ linear contrast between $0,0.91,1.81$, and $2.72 \mathrm{~kg}$ of extruded flaxseed $/ \mathrm{d} ; \mathrm{Q}=$ quadratic contrast between $0,0.91,1.81$, and $2.72 \mathrm{~kg}$ of extruded flaxseed $/ \mathrm{d} ; \mathrm{C}=$ cubic contrast between $0,0.91,1.81$, and $2.72 \mathrm{~kg}$ of extruded flaxseed $/ \mathrm{d} ; \mathrm{P}=$ effect of flaxseed processing; $1.81 \mathrm{~kg} / \mathrm{d}$ of extruded versus ground flaxseed.

${ }^{5}$ Saturated FA $=$ Cn- 0 .

${ }^{6}$ Athero $=$ sum of $\mathrm{C} 12: 0, \mathrm{C} 14: 0$, and $\mathrm{C} 16: 0$.

${ }^{7}$ Monounsaturated $\mathrm{FA}=\mathrm{Cn}-1$.

${ }^{8}$ Polyunsaturated $\mathrm{FA}=\mathrm{Cn}-2+$.

${ }^{9} \mathrm{UC}=$ unconjugated linoleic acid.

${ }^{10} \mathrm{CLA}=$ conjugated linoleic acid. 
Table 5. Effect of flaxseed supplementation rate and processing on milk FA composition

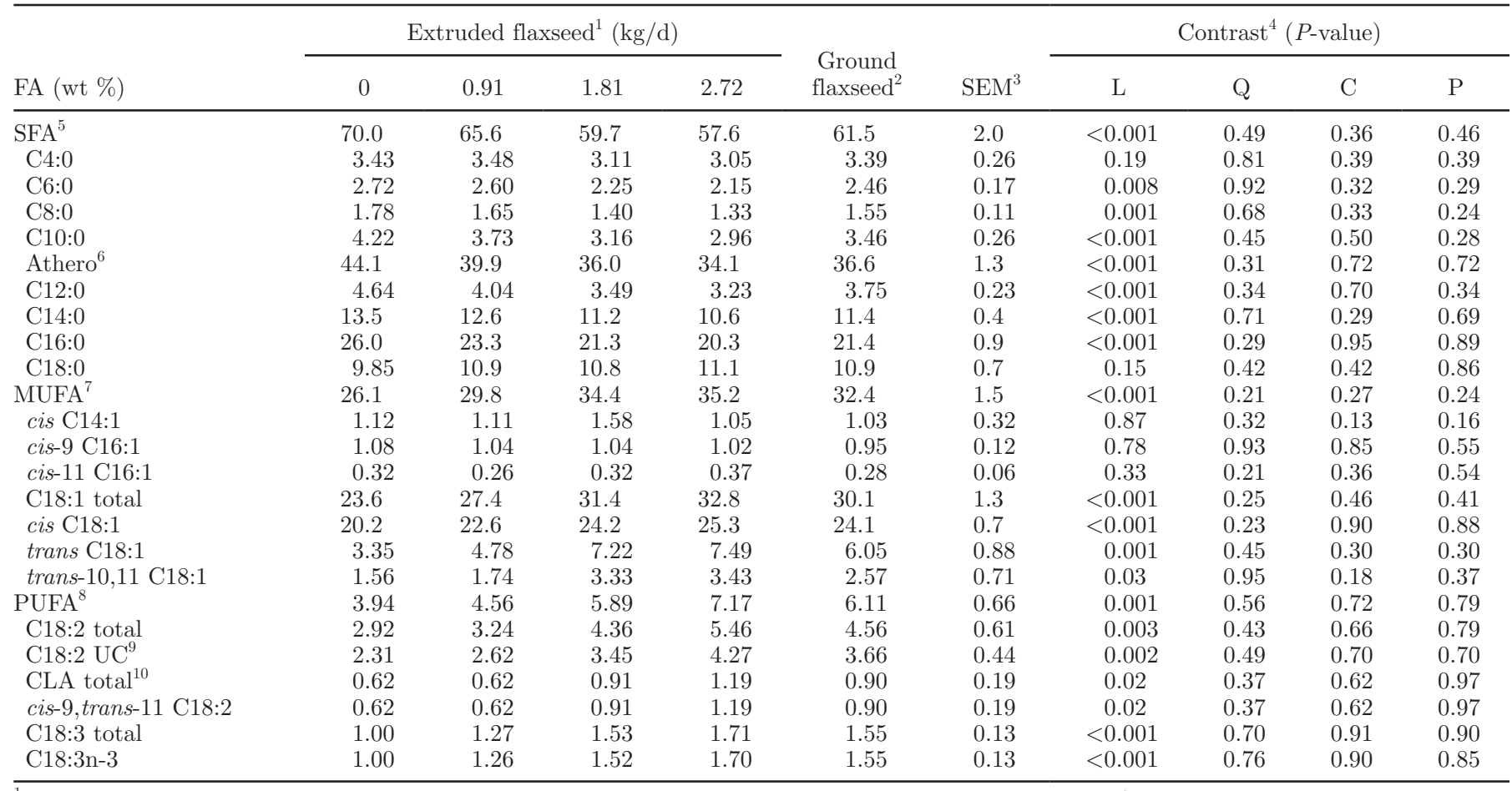

${ }^{1}$ Extruded flaxseed: $0=$ no additional lipid supplementation above that supplied by TMR; $0.91=0.28 \mathrm{~kg} / \mathrm{d}$ of supplemented fat from extruded flaxseed with $56 \%$ C18:3n-3; $1.81=0.56 \mathrm{~kg} / \mathrm{d}$ of supplemented fat from extruded flaxseed with $56 \%$ C18:3 n-3; $2.72=0.83 \mathrm{~kg} / \mathrm{d}$ of supplemented fat from extruded flaxseed with $56 \%$ C18:3n-3.

${ }^{2}$ Ground flaxseed: $1.81 \mathrm{~kg} / \mathrm{d}$ of ground flaxseed $=0.66 \mathrm{~kg} / \mathrm{d}$ of supplemented fat from ground flaxseed with $59 \%$ C18:3n-3.

${ }^{3}$ The largest $\mathrm{SE}$ of the 5 treatment groups is shown.

${ }^{4} \mathrm{~L}=$ linear contrast between $0,0.91,1.81$, and $2.72 \mathrm{~kg}$ of extruded flaxseed $/ \mathrm{d} ; \mathrm{Q}=$ quadratic contrast between $0,0.91,1.81$, and $2.72 \mathrm{~kg}$ of extruded flaxseed $/ \mathrm{d} ; \mathrm{C}=$ cubic contrast between $0,0.91,1.81$, and $2.72 \mathrm{~kg}$ of extruded flaxseed $/ \mathrm{d} ; \mathrm{P}=$ effect of flaxseed processing; $1.81 \mathrm{~kg} / \mathrm{d}$ of extruded versus ground flaxseed.

${ }^{5}$ Saturated $\mathrm{FA}=\mathrm{Cn}-0$.

${ }^{6}$ Athero $=$ sum of C12:0, C14:0, and C16:0.

${ }^{7}$ Monounsaturated FA $=$ Cn-1.

${ }^{8}$ Polyunsaturated $\mathrm{FA}=\mathrm{Cn}-2+$.

${ }^{9} \mathrm{UC}=$ unconjugated linoleic acid.

${ }^{10} \mathrm{CLA}=$ conjugated linoleic acid.

not significantly affect cheese FA composition (Table 7). Compared with milk fat, cheese fat had a lower proportion of FA up to C14:0 and a larger proportion of PUFA (Tables 5 and 7).

\section{Butter and Cheese Texture Analysis}

Flaxseed supplementation rate and processing did not affect butter yield on a solid basis; however, because we kept processing parameters constant, the moisture content of butter was greater if cows received flaxseed, regardless of supplementation rate and processing technique $(P=0.003$; Table 8$)$. Feeding 2.72 rather than 0 $\mathrm{kg}$ of $\mathrm{EF} / \mathrm{d}$ decreased the hardness of refrigerated butter by $58 \%\left(P_{\text {Linear }}=0.003\right)$ and the adhesiveness by $38 \%$ $\left(P_{\text {Linear }}=0.03\right.$; Table 8$)$. Adjusting for moisture content of the butter by covariate analysis did not alter significantly the estimates for refrigerated butter (results not shown). As expected from the melting temperatures of individual FA, the decreases in hardness and adhesiveness were smaller in butter at room temperature (Table 8) and attenuated to nonsignificance after adjusting for moisture content of butter (results not shown).

Flaxseed supplementation rate and processing did not affect the fresh Mozzarella cheese yield on a solid basis (Table 8). A quadratic effect of flaxseed supplementation rate on moisture and lipid content of cheese was observed; the effect, however, was not similar in magnitude among treatment groups (Table 8). Related to the comparatively low lipid content of fresh Mozzarella cheese, the effect of flaxseed supplementation rate on cheese texture was not significant (Table 8). 

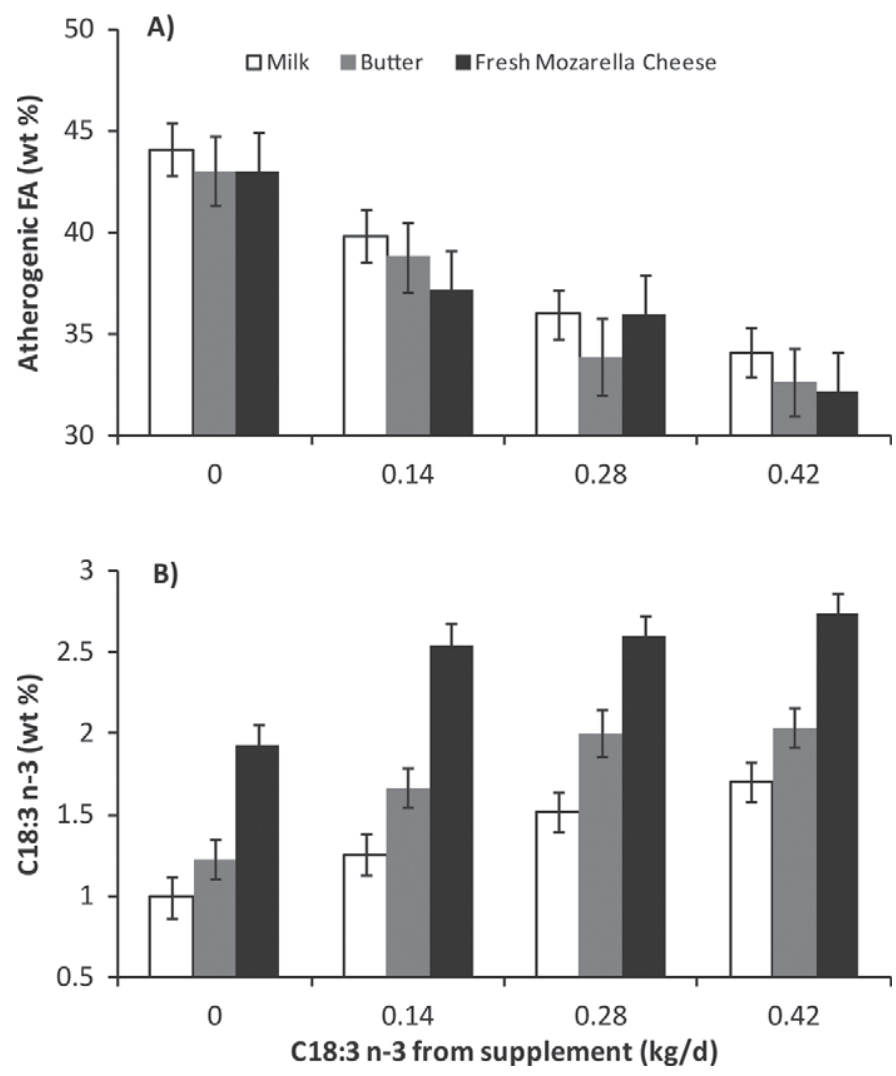

Figure 2. Effect of dietary C18:3n-3 supplementation rate by using extruded flaxseed on the FA profile of milk, butter, and cheese: (A) atherogenic FA; (B) C18:3n-3.

\section{DISCUSSION}

The objective of this study was to determine the optimal amount of EF supplementation for improving the FA profile without negatively affecting production characteristics for milk and dairy products. Supplementation of up to $2.72 \mathrm{~kg}$ of EF/d to mid- to late-lactation Holstein cows decreased the proportion of atherogenic FA and increased the proportion of C18:3n-3 in milk, butter, and fresh Mozzarella cheese, but did not decrease DMI, milk component concentrations, or production of milk, butter, and fresh Mozzarella cheese. Our results suggest that feeding up to $2.72 \mathrm{~kg}$ of EF/d to mid- to late-lactation Holstein cows is a potential management tool to improve the FA profile of milk and dairy products.

Supplementation of up to $2.72 \mathrm{~kg}$ of EF/d to mid- to late-lactation Holstein cows did not affect cow performance and production during the experimental period (Table 3). Similarly, Petit (2010) concluded in her review that feeding of up to $15 \%$ of DM as flaxseed, irrespective of processing method, had limited effect on DMI or milk production and composition. In contrast, feeding EF decreased DMI, milk production, or milk fat content in cows during mid to late lactation (Gonthier et al., 2005; Martin et al., 2008; Hurtaud et al., 2010). Feeding EF at 0, 3.0, or 6.2\% of the TMR for $7 \mathrm{wk}$ decreased linearly fat content in milk and butter and FCM (Hurtaud et al., 2010). Similarly, feeding EF at $12.7 \%$ of the TMR for $4 \mathrm{wk}$ decreased milk fat content compared with feeding raw flaxseed (Gonthier et al., 2005), and feeding EF at approximately $15 \%$ of the TMR DM for 4 wk decreased DMI, milk production, and milk fat content (Martin et al., 2008). The lower proportion of corn or corn silage (11.9 vs. 44 to $70 \%$ ) and higher proportion of grass silage and alfalfa hay in our TMR (59.5 vs. 0 to $21 \%$; Table 1) compared with previous studies (Gonthier et al., 2005; Martin et al., 2008; Hurtaud et al., 2010) may have limited the detrimental effect of PUFA on DMI, milk production, and milk fat content (Loor et al., 2005; Maia et al., 2007; Bradford et al., 2008).

Although we did not observe significant carryover effects in this and preliminary studies (results not shown), we cannot exclude the possibility that the supplementation period ( $2 \mathrm{wk}$ ) was too short to observe long-term EF effects. Changes in concentrations of milk fat (Kim et al., 1991) and milk protein (Casper et al., 1990) with fat supplementation may take $5 \mathrm{wk}$ or greater to become apparent. Future studies are warranted to examine the long-term effects of feeding up to $2.72 \mathrm{~kg} / \mathrm{d}$ of EF or flaxseed on production characteristics and health, as this information is currently not available (Petit, 2010).

Supplementation of up to $2.72 \mathrm{~kg}$ of $\mathrm{EF} / \mathrm{d}$, which included up to $0.42 \mathrm{~kg}$ of $\mathrm{C} 18: 3 \mathrm{n}-3 / \mathrm{d}$, almost doubled concentrations of C18:3n-3 in serum in a linear manner (Figure 1; Table 4). In addition, we observed a linear increase in cis C18:1 (Table 4). In support, Gonthier et al. (2005) reported that feeding $12.6 \% \mathrm{EF}$ on a DM basis doubled the proportion of $\mathrm{C} 18: 3 \mathrm{n}-3$ in plasma FA and increased the proportion of cis C18:1 in latelactation cows. Similarly, Zachut et al. (2010) reported that feeding 7.9 and $9.2 \% \mathrm{EF}$ on a DM basis increased the FA proportion of $\mathrm{C} 18: 3 \mathrm{n}-3$ in plasma of cows in the dry period and early lactation, respectively. These results indicate that a significant amount of dietary C18:3n-3 and cis C18:1 from EF is not saturated in the rumen and transferred unchanged to the duodenum, where it is absorbed. In contrast, Doreau et al. (2009) reported for dry cows that feeding $7.5 \% \mathrm{EF}$ on a DM basis primarily increased the proportion of unsaturated biohydrogenation products of $\mathrm{C} 18: 3 \mathrm{n}-3$ in plasma but not $\mathrm{C} 18: 3 \mathrm{n}-3$ and cis $\mathrm{C} 18: 1$ themselves. The lower proportion of corn and corn silage in the TMR of our study $(11.9 \%)$, in the study of Gonthier et al. $(2005 ; 20.7 \%)$, and in the study of Zachut et al. (2010; $11.8 \%$ in dry cows and $24.5 \%$ in lactating cows) compared with the study of Doreau et al. $(2009 ; 63 \%)$ may have improved 
Table 6. Effect of flaxseed supplementation rate and processing on butter FA composition

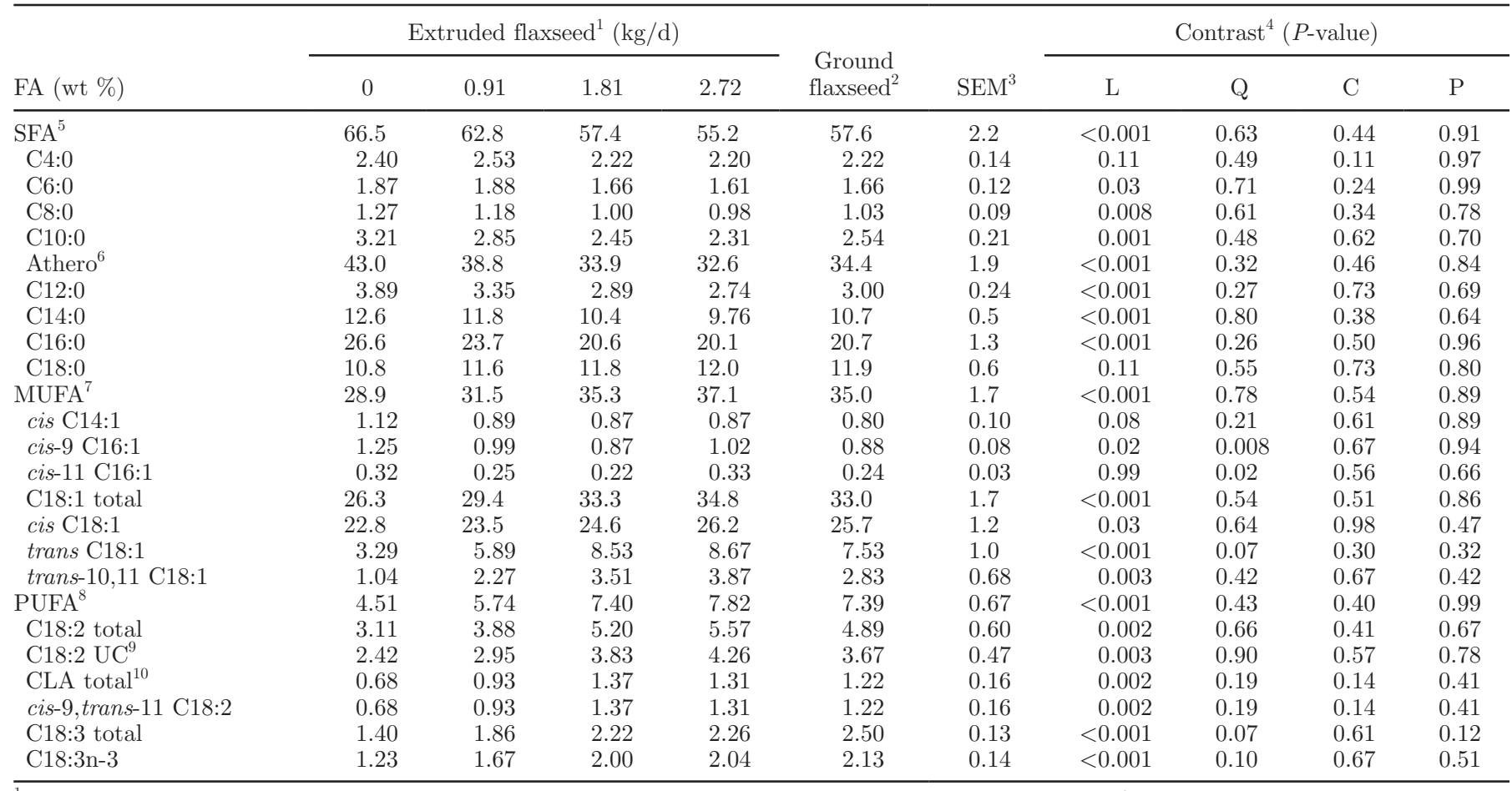

${ }^{1}$ Extruded flaxseed: $0=$ no additional lipid supplementation above that supplied by TMR; $0.91=0.28 \mathrm{~kg} / \mathrm{d}$ of supplemented fat from extruded flaxseed with $56 \%$ C18:3n-3; $1.81=0.56 \mathrm{~kg} / \mathrm{d}$ of supplemented fat from extruded flaxseed with $56 \%$ C18:3n-3; $2.72=0.83 \mathrm{~kg} / \mathrm{d}$ of supplemented fat from extruded flaxseed with $56 \%$ C18:3n-3.

${ }^{2}$ Ground flaxseed: $1.81 \mathrm{~kg} / \mathrm{d}$ of ground flaxseed $=0.66 \mathrm{~kg} / \mathrm{d}$ of supplemented fat from ground flaxseed with $59 \% \mathrm{C} 18: 3 \mathrm{n}-3$.

${ }^{3}$ The largest $\mathrm{SE}$ of the 5 treatment groups is shown.

${ }^{4} \mathrm{~L}=$ linear contrast between $0,0.91,1.81$, and $2.72 \mathrm{~kg}$ of extruded flaxseed $/ \mathrm{d} ; \mathrm{Q}=$ quadratic contrast between $0,0.91,1.81$, and $2.72 \mathrm{~kg}$ of extruded flaxseed $/ \mathrm{d} ; \mathrm{C}=$ cubic contrast between $0,0.91,1.81$, and $2.72 \mathrm{~kg}$ of extruded flaxseed $/ \mathrm{d} ; \mathrm{P}=$ effect of flaxseed processing; $1.81 \mathrm{~kg} / \mathrm{d}$ of extruded versus ground flaxseed.

${ }^{5}$ Saturated $\mathrm{FA}=\mathrm{Cn}-0$.

${ }^{6}$ Athero $=$ sum of C12:0, C14:0, and C16:0.

${ }^{7}$ Monounsaturated FA $=$ Cn-1.

${ }^{8}$ Polyunsaturated $\mathrm{FA}=\mathrm{Cn}-2+$.

${ }^{9} \mathrm{UC}=$ unconjugated linoleic acid.

${ }^{10} \mathrm{CLA}=$ conjugated linoleic acid.

rumen bypass of dietary C18:3n-3 and cis C18:1 from $\mathrm{EF}$ to the duodenum.

The linear increase in C18:3n-3 concentrations in plasma, as a result of feeding of up to $0.42 \mathrm{~kg}$ of C18:3n-3/d from EF, is reflected in a linear increase in C18:3n-3 in milk fat (Figure 2B). In support, Hurtaud et al. (2010) reported a gradual increase in C18:3n-3 in milk fat, when cows in mid to late lactation were fed EF at 0,21 , or $4.3 \%$ of the ration. Similarly, Collomb et al. (2004) reported for mid-lactation cows that feeding $0,1.0$, and $1.4 \mathrm{~kg}$ of ground flaxseed linearly increased C18:3n-3 in milk fat. Whereas the proportion of C18:3n-3 increased in milk fat, the proportion of the atherogenic FA (C12:0, C14:0, and C16:0) linearly decreased in milk fat in response to feeding up to 0.42 $\mathrm{kg}$ of C18:3n-3/d of from EF (Figure 2A). Similar re- sults have been reported by Collomb et al. (2004) and Hurtaud et al. (2010). An increase in dietary lipids that are enriched in PUFA decreased de novo FA synthesis (C6 to C16) in the mammary gland (as reviewed by Glasser et al., 2008a). Glasser et al. (2008b) proposed that when the proportion of $\mathrm{C} 18$ in milk fat exceeds $52 \%$, dietary lipids limit de novo FA synthesis to such an extent that milk fat synthesis and duodenal absorption of C18 are decreased. In our study, feeding $2.72 \mathrm{~kg}$ of $\mathrm{EF} / \mathrm{d}$ increased the proportion of $\mathrm{C} 18$ in milk to $51 \%$ (Table 5). Thus, feeding more than $2.72 \mathrm{~kg}$ of $\mathrm{EF} / \mathrm{d}$ may limit milk fat content.

The FA profile of butter fat (Table 6) and fresh Mozzarella cheese fat (Table 7) resembled the FA profile of milk fat (Table 5) in response to feeding up to 2.72 $\mathrm{kg}$ of $\mathrm{EF} / \mathrm{d}$. Our results are consistent with previous 
Table 7. Effect of flaxseed supplementation rate and processing on fresh Mozzarella cheese FA composition

\begin{tabular}{|c|c|c|c|c|c|c|c|c|c|c|}
\hline FA (wt \%) & \multicolumn{4}{|c|}{ Extruded flaxseed $^{1}(\mathrm{~kg} / \mathrm{d})$} & $\begin{array}{l}\text { Ground } \\
\text { flaxseed }^{2}\end{array}$ & $\mathrm{SEM}^{3}$ & \multicolumn{4}{|c|}{ Contrast $^{4}$ ( $P$-value $)$} \\
\hline$\overline{\mathrm{SFA}^{5}}$ & 67.3 & 61.6 & 59.5 & 55.2 & 58.7 & 2.7 & 0.01 & 0.80 & 0.57 & 0.84 \\
\hline $\mathrm{C} 6: 0$ & 2.09 & 1.94 & 1.88 & 1.89 & 2.07 & 0.16 & 0.41 & 0.61 & 0.96 & 0.45 \\
\hline $\mathrm{C} 8: 0$ & 1.40 & 1.24 & 1.19 & 1.16 & 1.31 & 0.11 & 0.17 & 0.58 & 0.82 & 0.49 \\
\hline C10:0 & 3.45 & 2.96 & 2.84 & 2.62 & 3.04 & 0.25 & 0.04 & 0.58 & 0.63 & 0.58 \\
\hline C16:0 & 26.4 & 21.9 & 21.6 & 19.3 & 20.2 & 1.3 & 0.003 & 0.37 & 0.21 & 0.44 \\
\hline C18:0 & 9.81 & 11.6 & 10.9 & 11.0 & 11.2 & 0.3 & 0.04 & 0.03 & 0.07 & 0.49 \\
\hline MUFA $^{7}$ & 26.8 & 31.2 & 33.3 & 36.2 & 33.4 & 2.2 & 0.01 & 0.71 & 0.69 & 0.96 \\
\hline cis $\mathrm{C} 14: 1$ & 1.05 & 0.99 & 1.03 & 0.91 & 0.95 & 0.07 & 0.17 & 0.54 & 0.18 & 0.33 \\
\hline cis-9 C16:1 & 1.26 & 1.07 & 0.95 & 1.02 & 0.92 & 0.08 & 0.03 & 0.06 & 0.58 & 0.83 \\
\hline cis-11 C16:1 & 0.30 & 0.29 & 0.24 & 0.29 & 0.28 & 0.03 & 0.45 & 0.20 & 0.14 & 0.31 \\
\hline C18:2 total & 3.58 & 4.06 & 3.99 & 5.31 & 4.50 & 0.53 & 0.06 & 0.41 & 0.35 & 0.51 \\
\hline $\mathrm{C} 18: 2 \mathrm{UC}^{9}$ & 2.73 & 3.15 & 3.16 & 4.15 & 3.48 & 0.39 & 0.04 & 0.44 & 0.36 & 0.56 \\
\hline CLA total ${ }^{10}$ & 0.85 & 0.92 & 0.84 & 1.15 & 1.01 & 0.17 & 0.33 & 0.47 & 0.45 & 0.50 \\
\hline cis-9,trans-11 C18:2 & 0.85 & 0.92 & 0.84 & 1.15 & 1.01 & 0.17 & 0.33 & 0.47 & 0.45 & 0.50 \\
\hline C18:3 total & 2.43 & 3.12 & 3.20 & 3.30 & 3.29 & 0.14 & $<0.001$ & 0.05 & 0.29 & 0.65 \\
\hline C18:3n-3 & 1.93 & 2.55 & 2.60 & 2.74 & 2.69 & 0.13 & 0.001 & 0.08 & 0.25 & 0.64 \\
\hline
\end{tabular}

${ }^{1}$ Extruded flaxseed: $0=$ no additional lipid supplementation above that supplied by TMR; $0.91=0.28 \mathrm{~kg} / \mathrm{d}$ of supplemented fat from extruded flaxseed with $56 \%$ C18:3n-3; $1.81=0.56 \mathrm{~kg} / \mathrm{d}$ of supplemented fat from extruded flaxseed with $56 \%$ C18:3n-3; $2.72=0.83 \mathrm{~kg} / \mathrm{d}$ of supplemented fat from extruded flaxseed with $56 \%$ C18:3n-3.

${ }^{2}$ Ground flaxseed:1.81 kg/d of ground flaxseed $=0.66 \mathrm{~kg} / \mathrm{d}$ of supplemented fat from ground flaxseed with $59 \% \mathrm{C} 18: 3 \mathrm{n}-3$.

${ }^{3}$ The largest $\mathrm{SE}$ of the 5 treatment groups is shown.

${ }^{4} \mathrm{~L}=$ linear contrast between $0,0.91,1.81$, and $2.72 \mathrm{~kg}$ of extruded flaxseed $/ \mathrm{d} ; \mathrm{Q}=$ quadratic contrast between $0,0.91,1.81$, and $2.72 \mathrm{~kg}$ of extruded flaxseed $/ \mathrm{d} ; \mathrm{C}=$ cubic contrast between $0,0.91,1.81$, and $2.72 \mathrm{~kg}$ of extruded flaxseed $/ \mathrm{d} ; \mathrm{P}=$ effect of flaxseed processing; $1.81 \mathrm{~kg} / \mathrm{d}$ of extruded versus ground flaxseed.

${ }^{5}$ Saturated $\mathrm{FA}=\mathrm{Cn}-0$.

${ }^{6}$ Athero $=$ sum of $\mathrm{C} 12: 0, \mathrm{C} 14: 0$, and $\mathrm{C} 16: 0$.

${ }^{7}$ Monounsaturated $\mathrm{FA}=\mathrm{Cn}-1$.

${ }^{8}$ Polyunsaturated $\mathrm{FA}=\mathrm{Cn}-2+$.

${ }^{9} \mathrm{UC}=$ unconjugated linoleic acid.

${ }^{10} \mathrm{CLA}=$ conjugated linoleic acid.

studies reporting that the FA profile of butter fat from cows (Hurtaud et al., 2010) and Manchego cheese fat from ewes (Gómez-Cortés et al., 2009) reflected the changes in milk fat in response to feeding EF. The current results indicate that only minor changes in FA profile occur during the butter and cheese manufacturing process of milk fat from EF-fed cows. Similar to the milk FA profile, supplementation of up to $2.72 \mathrm{~kg}$ of $\mathrm{EF} / \mathrm{d}$, which included up to $0.42 \mathrm{~kg}$ of $\mathrm{C} 18: 3 \mathrm{n}-3 / \mathrm{d}$, linearly increased the proportion of $\mathrm{C} 18: 3 \mathrm{n}-3$ in butter and cheese fat (Figure 2B) and decreased the proportion of atherogenic FA in butter and cheese fat (Figure $2 A$ ). Such changes in FA profile are consistent with dietary recommendations by human nutritionists to limit the consumption of SFA to $10 \%$ and to increase the intake of n- 6 and n- 3 PUFA to between 3 and $10 \%$ and between 0.6 and $1.2 \%$ of the energy intake, respectively (IOM, 2002; Kris-Etherton et al., 2007).

Supplementation of up to $2.72 \mathrm{~kg}$ of EF/d to lactating Holstein cows did not affect the yield on a solid basis of butter and fresh Mozzarella cheese (Table 8). Hurtaud et al. (2010) reported that feeding EF at $4.3 \%$ of the ration increased the fat lost in the butter milk during churning. Lowering the churning temperature and decreasing the initial churning speed avoided such losses, which are caused by the altered crystallization behavior of milk fat from EF-fed cows (Smet et al., 2010). By using constant processing conditions, the moisture content of butter was greater if cows received EF or flaxseed compared with no supplementation (Table 8). This result is similar to what had been previously reported by Hurtaud et al. (2010) when cows were fed EF 
Table 8. Effect of flaxseed supplementation rate and processing on yield and texture of butter and fresh Mozzarella cheese

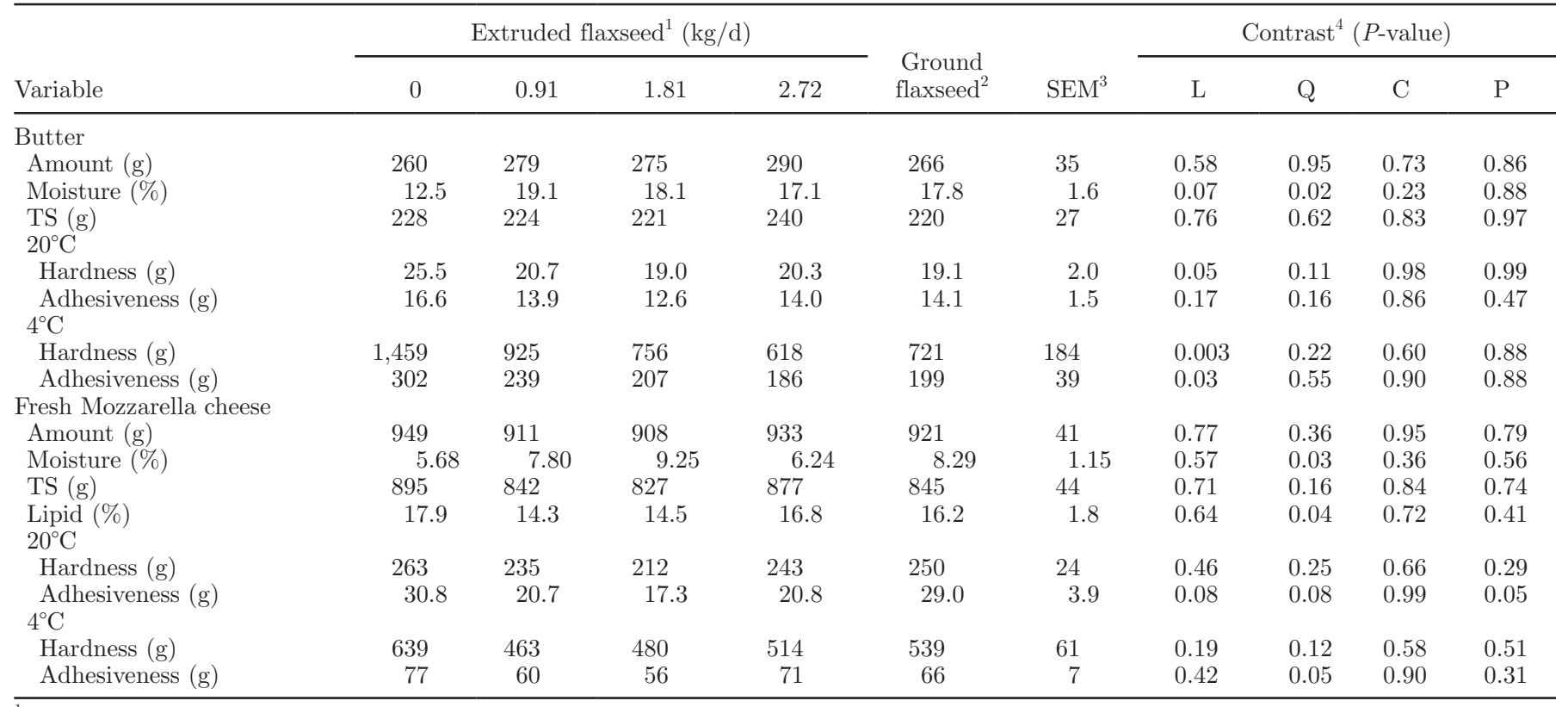

${ }^{1}$ Extruded flaxseed: $0=$ no additional lipid supplementation above that supplied by TMR; $0.91=0.28 \mathrm{~kg} / \mathrm{d}$ of supplemented fat from extruded flaxseed with $56 \%$ C18:3n- $3 ; 1.81=0.56 \mathrm{~kg} / \mathrm{d}$ of supplemented fat from extruded flaxseed with $56 \%$ C18:3n-3; $2.72=0.83 \mathrm{~kg} / \mathrm{d}$ of supplemented fat from extruded flaxseed with $56 \%$ C18:3n-3.

${ }^{2}$ Ground flaxseed: $1.81 \mathrm{~kg} / \mathrm{d}$ of ground flaxseed $=0.66 \mathrm{~kg} / \mathrm{d}$ of supplemented fat from ground flaxseed with $59 \%$ C18:3n-3.

${ }^{3}$ The largest standard error of the 5 treatment groups is shown.

${ }^{4} \mathrm{~L}=$ linear contrast between $0,0.91,1.81$, and $2.72 \mathrm{~kg}$ of extruded flaxseed $/ \mathrm{d} ; \mathrm{Q}=$ quadratic contrast between $0,0.91,1.81$, and $2.72 \mathrm{~kg}$ of extruded flaxseed $/ \mathrm{d} ; \mathrm{C}=$ cubic contrast between $0,0.91,1.81$, and $2.72 \mathrm{~kg}$ of extruded flaxseed $/ \mathrm{d} ; \mathrm{P}=$ effect of flaxseed processing; $1.81 \mathrm{~kg} / \mathrm{d}$ of extruded versus ground flaxseed.

at $4.3 \%$ of the ration. Feeding up to $2.72 \mathrm{~kg}$ of $\mathrm{EF} / \mathrm{d}$ to lactating Holstein cows linearly decreased hardness and adhesiveness of refrigerated butter, which likely cause improved spreadability (Table 8). Similarly, Hurtaud et al. (2010) reported that feeding $\mathrm{EF}$ at $4.3 \%$ of the ration decreased the firmness of butter at 4 and $13^{\circ} \mathrm{C}$ and improved butter spreadability and melt-in-the-mouth texture. Our results suggest that supplementation of up to $2.72 \mathrm{~kg}$ of EF/d to lactating Holstein cows may improve textural properties of refrigerated butter.

\section{CONCLUSIONS}

Supplementation of up to $2.72 \mathrm{~kg}$ of $\mathrm{EF} / \mathrm{d}$ to midto late-lactation Holstein cows linearly decreased the proportion of atherogenic FA and linearly increased the proportion of C18:3n-3 in milk, butter, and fresh Mozzarella cheese, but did not decrease production characteristics of milk, butter, or fresh Mozzarella cheese. Mid- to late-lactation cows can be fed up to $2.72 \mathrm{~kg}$ of $\mathrm{EF} / \mathrm{d}$ to improve the nutritional and textural profile of milk and dairy products and warrants to be confirmed in EF feeding studies throughout mid to late lactation.

\section{ACKNOWLEDGMENTS}

This study was financially supported by Double Pass LLC (Tualatin, OR) and Oregon State University (Corvallis). The authors acknowledge the staff of the Oregon State Dairy Farm, K. Hayes, A. Lulay, P. Oeffner, R. Oeffner, K. Oswald, and C. Shriver-Munsch (all in the Department of Animal and Rangeland Sciences, Oregon State University, Corvallis) for their assistance with feeding, sample collection, and butter and cheese manufacture; and C. Depner and D. Jump (College of Public Health and Human Sciences) for their assistance with FA analysis.

\section{REFERENCES}

AOAC (Association of Official Analytical Chemists). 1990. Official Methods of Analysis. Vol. I. 15th ed. AOAC, Arlington, VA.

AOCS (American Oil Chemists' Society). 2004. AOCS Approved Procedure Am 5-04. Rapid determination of oil/fat utilizing high temperature solvent extraction. Accessed June 18, 2012. http://www. taisa.co.cr/Productos/Ankom/pdf/Metodo_AOCS_Am_5-04.pdf.

Bean, L. D., and S. Leeson. 2002. Fatty acid profiles of 23 samples of flaxseed collected from commercial feed mills in Ontario in 2001. J. Appl. Poult. Res. 11:209-211. 
Bradford, B. J., K. J. Harvatine, and M. S. Allen. 2008. Dietary unsaturated fatty acids increase plasma glucagon-like peptide-1 and cholecystokinin and may decrease premeal ghrelin in lactating cows. J. Dairy Sci. 91:1443-1450.

Casper, D. P., D. J. Schingoethe, and W. A. Eisenbeisz. 1990. Response of early lactation cows to diets that vary in ruminal degradability of carbohydrates and amount of fat. J. Dairy Sci. 73:425-444.

Collomb, M., H. Sollberger, U. Bütikofer, R. Sieber, W. Stoll, and W. Schaeren. 2004. Impact of a basal diet of hay and fodder beet supplemented with rapeseed, linseed and sunflowerseed on the fatty acid composition of milk fat. Int. Dairy J. 14:549-559.

Doreau, M., S. Laverroux, J. Normand, G. Chesneau, and F. Glasser. 2009. Effect of linseed fed as rolled seeds, extruded seeds or oil on fatty acid rumen metabolism and intestinal digestibility in cows. Lipids 44:53-62.

Drewnowski, A. 2011. The contribution of milk and milk products to micronutrient density and affordability of the U.S. diet. J. Am. Coll. Nutr. 30:422S-428S.

Federation of Animal Science Societies (FASS). 2010. Guide for the Care and Use of Agricultural Animals in Research and Teaching. 3rd ed. Accessed Jul. 26, 2012. http://www.fass.org/docs/agguide3rd/Ag_Guide_3rd_ed.pdf.

Folch, J., M. Lees, and G. H. Sloane Stanley. 1957. A simple method for the isolation and purification of total lipids from animal tissues. J. Biol. Chem. 226:497-509.

Glasser, F., A. Ferlay, and Y. Chilliard. 2008a. Oilseed lipid supplements and fatty acid composition of cow milk: A meta-analysis. J. Dairy Sci. 91:4687-4703.

Glasser, F., A. Ferlay, M. Doreau, P. Schmidely, D. Sauvant, and Y. Chilliard. 2008b. Long-chain fatty acid metabolism in dairy cows: A meta-analysis of milk fatty acid yield in relation to duodenal flows and de novo synthesis. J. Dairy Sci. 91:2771-2785.

Gómez-Cortés, P., A. Bach, P. Luna, M. Juárez, and M. A. de la Fuente. 2009. Effects of extruded linseed supplementation on n-3 fatty acids and conjugated linoleic acid in milk and cheese from ewes. J. Dairy Sci. 92:4122-4134.

Gonthier, C., A. F. Mustafa, D. R. Ouellet, P. Y. Chouinard, R. Berthiaume, and H. V. Petit. 2005. Feeding micronized and extruded flaxseed to dairy cows: Effects on blood parameters and milk fatty acid composition. J. Dairy Sci. 88:748-756.

Haug, A., A. T. Høstmark, and O. M. Harstad. 2007. Bovine milk in human nutrition-A review. Lipids Health Dis. 6:25.

Hurtaud, C., F. Faucon, S. Couvreur, and J. L. Peyraud. 2010. Linear relationship between increasing amounts of extruded linseed in dairy cows diet and milk fatty acid composition and butter properties. J. Dairy Sci. 93:1429-1443.

IOM (Institute of Medicine). 2002. Dietary Reference Intakes for Energy, Carbohydrate, Fiber, Fat, Fatty Acids, Cholesterol, Protein, and Amino Acids. Nat. Acad. Sci., Washington, DC.

Kim, Y. K., D. J. Schingoethe, D. P. Casper, and F. C. Ludens. 1991. Lactational response of dairy cows to increased dietary crude protein with added fat. J. Dairy Sci. 74:3891-3899.

Kris-Etherton, P. M., and S. Innis., American Dietetic Association, and Dietitians of Canada. 2007. Position of the American Dietetic Association and Dietitians of Canada: Dietary fatty acids. J. Am. Diet. Assoc. 107:1599-1611.

Loor, J. J., A. Ferlay, A. Ollier, M. Doreau, and Y. Chilliard. 2005. Relationship among trans and conjugated fatty acids and bovine milk fat yield due to dietary concentrate and linseed oil. J. Dairy Sci. 88:726-740.

Maia, M. R. G., L. C. Chaudhary, L. Figueres, and R. J. Wallace. 2007. Metabolism of polyunsaturated fatty acids and their toxicity to the microflora of the rumen. Antonie van Leeuwenhoek 91:303-314.

Martin, C., J. Rouel, J. P. Jouany, M. Doreau, and Y. Chilliard. 2008 Methane output and diet digestibility in response to feeding dairy cows crude linseed, extruded linseed, or linseed oil. J. Anim. Sci. $86: 2642-2650$.

NRC. 2001. Nutrient Requirements of Dairy Cattle. 7th rev. ed. National Acad. Sci., Washington, DC.

Petit, H. V. 2010. Review: Feed intake, milk production and milk composition of dairy cows fed flaxseed. Can. J. Anim. Sci. 90:115-127.

SAS Institute. 2001. SAS User's Guide: Statistics. Version 9.1. SAS Inst. Inc., Cary, NC.

Smet, K., K. Coudijzer, E. Fredrick, S. De Campeneere, J. De Block, J. Wouters, K. Raes, and K. Dewettinck. 2010. Crystallization behavior of milk fat obtained from linseed-fed cows. J. Dairy Sci. 93:495-505.

USDA and HHS (US Department of Agriculture and US Department of Health and Human Services). 2010. Dietary Guidelines for Americans, 2010. 7th ed. US Government Printing Office, Washington, DC.

Zachut, M., A. Arieli, H. Lehrer, L. Livshitz, S. Yakoby, and U. Moallem. 2010. Effects of increased supplementation of n-3 fatty acids to transition dairy cows on performance and fatty acid profile in plasma, adipose tissue, and milk fat. J. Dairy Sci. 93:5877-5889. 